\title{
Sprawozdanie z Kongresu Profesjonalistów PR 18-19.04.2013
}

$\mathbf{K}^{\circ}$ ongres Profesjonalistów PR jest jednym z najważniejszych wydarzeń związanych z branżą Public Relations w naszym kraju. Tegoroczna edycja odbyła się w Rzeszowie 18 oraz 19 kwietnia 2013 roku i była organizowana między innymi przez Polskie Stowarzyszenie Public Relations oraz Uniwersytet Wrocławski. Pewną nowością w stosunku do poprzednich edycji było zainicjowanie, w ramach Kongresu Profesjonalistów, nowego przedsięwzięcia - Kongresu YoungPR 2013 oraz ogólnopolskiego konkursu o tej samej nazwie. Formuła imprezy została przedłużona o dwa dodatkowe dni, w czasie których profesjonaliści wygłaszali prelekcje i organizowali warsztaty skierowane do studentów. Spotkanie odbywało się w terminie bezpośrednio poprzedzającym Kongres Profesjonalistów (16 i 17 kwietnia), na wydziale Dziennikarstwa i Komunikacji Społecznej we Wrocławiu.

Właściwe wydarzenie zorganizowano w czterogwiazdkowym Hotelu Rzeszów, uczestniczyło w nim ponad dwieście osób (w tym trzydziestu prelegentów), które w dużym stopniu związane były z branżą Public Relations. Mimo sporej różnorodności zagadnień omawianych w czasie prelekcji, głównym problemem przewijającym się w tle poruszanych tematów była przyszłość PR, pytania o to, dokąd zmierza i czy jeszcze się rozwija. Poglądy prelegentów na temat zmian w public relations czasami znacznie się różniły, lecz wszyscy zgodnie zauważali, że jesteśmy świadkami ogromnej zmiany w modelu efektywnej komunikacji, głównie z powodu rozwoju internetu i technologii. Prelekcję otwierającą pierwszy dzień Kongresu Profesjonalistów tradycyjnie wygłosił Adam Łaszyn z agencji Alert Media Communications. W swoim wystąpieniu omówił najważniejsze, jego zdaniem, wydarzenia z branży public relations, temat doskonały na otwarcie imprezy, trafnie podsumowujący zeszłoroczne highlighty. Niestety z racji dużej liczby prelekcji nie sposób zrecenzować wystąpienia wszystkich prelegentów. Skupię się na osobach, które za pośrednictwem swoich prezentacji wniosły dużo świeżości do analizy nowych trendów 
i dyskusji na temat głównych problemów. W pierwszej kolejności należy wymienić Szymona Sikorskiego, który w swoim wystąpieniu, posiłkując się wynikami aktualnych badań, poruszał m.in. temat redefinicji pojęcia komunikacji w obliczu wyzwań związanych z rosnącą ilością danych, a także społeczną użytecznością miejskiego designu. Kolejne wystąpienie, również zachowane w emocjonującym tonie, należało do Pawła Trochimiuka. Tezy stawiane $\mathrm{w}$ prezentacji nieco różniły się od tych stawianych przez Sikorskiego. Widoczny był pewien sceptycyzm, związany z rozwojem technologii i interaktywnymi narzędziami pracy PR-owca. Wnioski z prezentacji mogły nieco ostudzić entuzjazm związany z social media czy e-PR, gdyż autor próbował wykazać, że to komunikacja realizowana w sposób bezpośredni nadal jest najskuteczniejszym kanałem przepływu informacji i że nic w ciągu najbliższych kilku lat w tej kwestii się nie zmieni. Kolejne wystąpienia warte wynotowania nie tyle dotyczyły samej istoty public relations, co narzędzi, jakimi współczesny PR-owiec może się posługiwać. Jan Zając z firmy Sotrender, na przykładzie użyteczności aplikacji analizującej i optymalizującej komunikację w mediach społecznościowych, próbował pokazać punkty zapalne, przyczyny i rozwój kryzysu komunikacyjnego na przykładzie wybranych marek, przypominając tym samym, że kompetencje samych agencji muszą ewoluować wraz z rozwojem narzędzi. Ostatnim, zamykającym pierwszy dzień Kongresu prelegentem był Michał Sadowski z firmy Brand24, zajmującej się monitoringiem nowych mediów. Przedstawił niezwykle ciekawe case studies związane z użytecznością swojego narzędzia. Pokazał również, że monitoring internetu to absolutna podstawa działań komunikacyjnych i bardzo ważny element w budowaniu strategii PR. Podczas ostatniej prelekcji udało się zaobserwować ciekawe zjawisko, na podstawie którego można wyciągnąć raczej smutne wnioski. Obserwując publiczność żywo reagującą na kampanie prezentowane przez Michała Sadowskiego, odnosiło się wrażenie, że duża część osób pierwszy raz miała styczność z ww. projektami. Może to świadczyć o jednym - o tym, że branża PR nie śledzi najnowszych trendów, gdyż były to case studies gorąco omawiane w mediach branżowych kilka-kilkanaście miesięcy wcześniej. Dlatego istnieje realna potrzeba większej liczby takich spotkań i większej częstotliwości takich imprez, na których będzie możliwość doedukowania i podnoszenie swoich kwalifikacji.

Drugi dzień Kongresu Profesjonalistów rozpoczynał się kontynuacją wątku narzędzi PR. Jerzy Hanus z Vegacom przedstawiał nowoczesne narzędzie służące do organizacji profesjonalnej wideokonferencji, które w pewien 
sposób może zrewolucjonizować kształt komunikacji na odległość. Następnie odbyła się debata związana z wcześniej opisanymi problemami - głównie rozwojem lub brakiem rozwoju branży PR. Moderacja samej dyskusji i argumenty dyskutantów mogły jednak utwierdzić w przekonaniu, że branża, mimo ponad dwudziestoletniej obecności na polskim rynku, nadal potrzebuje solidnej edukacji. Mogły również utwierdzić w tym, że PR wciąż potrzbuje dobrego PR-u. Po debacie odbyły się kolejne prelekcje oraz warsztaty prowadzone przez pracowników agencji PR. 